Int. J. Morphol.,

33(2):678-684, 2015.

\title{
Anthropometric Landmarks for Posterior Cruciate Ligament Reconstruction in Anatomical Position
}

\author{
Referencias Antropométricas para la Reconstrucción del \\ Ligamento Cruzado Posterior en Posición Anatómica
}

\begin{abstract}
Gustavo Adolfo Compeán-Martínez*; Rodolfo Morales-Avalos*; Félix Vílchez-Cavazos**; Carlos Acosta-Olivo**; Oscar Fernando Mendoza-Lemus**; Oscar de la Garza-Castro*; Rodrigo E. Elizondo-Omaña* \& Santos Guzmán-López*
\end{abstract}

COMPEÁN-MARTÍNEZ, G. A.; MORALES-AVAloS, R.; VÍlCHEZ-CAVAZOS, F.; ACOSTA-OLIVO, C.; MENDOZALEMUS, O. F.; GARZA-CASTRO, O.; ELIZONDO-OMAÑA, R. E. \& GUZMÁN-LÓPEZ, S. Anthropometric landmarks for posterior cruciate ligament reconstruction in anatomical position. Int. J. Morphol., 33(2):678-684, 2015.

SUMMARY: To determine viable anatomical landmarks allowing for accurate femoral and tibial tunnel placement in anatomical position during posterior cruciate ligament (PCL) reconstruction. Ten knees were dissected to analyze femoral and tibial PCL insertion measurements and the features specific to the PCL and its fascicles. The clock hands system was used to measure femoral insertions. The meniscus and anterior cruciate ligament (ACL) were used as landmarks to measure tibial insertions. The PCL and its corresponding fascicle characteristics were determined by its femoral insertion, central portion and tibial insertion. The mean lengths between the central point of the PCL footprint and the articular cartilage border at 12:00 h were $17.23 \mathrm{~mm}( \pm 3.94)$ and $17.73 \mathrm{~mm}( \pm 4.11)$ for the right and left knees, respectively. The anterior-posterior mean lengths for the PCL were $11.94 \mathrm{~mm}( \pm 5.08)$ between the posterior PCL border and the anterior PCL border. The mean lengths were $33.52 \mathrm{~mm}( \pm 3.49)$ from the medial border of the lateral meniscus to the lateral PCL border and $32.24 \mathrm{~mm}( \pm 2.28)$ from the medial border of the medial meniscus to the medial PCL border. From the anteroposterior viewpoint, the anterolateral fascicle is greater than the posteromedial one in its femoral and tibial insertions and in its central portion. A quantitative data collection summary was conducted with different PCL variables, along with its fascicles and their various femoral and tibial bony landmarks. Various measurements were obtained, indicating the high functionality shared by the PCL fascicles. Lengths reported for insertions are practical landmarks for the locations of femoral and tibial tunnels during posterior cruciate ligament plasty. We must take into account native PCL form to avoid oversizing the graft during reconstruction and to avoid a possible clamping of the graft with the surrounding structures.

KEY WORDS: Posterior cruciate ligament; Femoral tunnels; Reconstruction; Anatomy; Landmark.

\section{INTRODUCTION}

The posterior cruciate ligament (PCL) is the ligament of greatest resistance associated with the knee joint. The PCL presents with anterolateral (AL) and posteromedial (PM) fascicles and is named for its femoral insertion. Its insertions cover a greater surface area compared to anterior cruciate ligament (ACL) insertions (Amis et al., 2003; Kennedy et al., 1976; Marinozzi et al., 1983; Race \& Amis, 1994). Those fascicles have multiple functions when the knee is in flexion or extension (Amis et al., 2006).

From an anatomical viewpoint, the area covered by the AL fascicle represents $85 \%$ of the central part of the femoral condyle (Edwards et al., 2007), which is why the procedure used in PCL reconstruction has involved replacing the PCL with a single bundle. For this procedure, one of the tendons of the ischiotibial muscles is used. However, from a functional point of view, the AL and PM fascicles are considered to contribute equally to joint stability. This functional consideration has had implications in PCL reconstruction procedures. There are currently attempts to simulate PCL biomechanics by utilizing a double bundle, in addition to accurate placement of the femoral and tibial tunnels during the procedure (Apsingi et al., 2009). There is controversy as to whether the PCL reconstruction technique is more appropriately performed using one or two bundles (Apsingi et al; Markolf et al., 2006; Amis et al., 2003).

* Department of Human Anatomy, Faculty of Medicine, Universidad Autonóma de Nuevo León (U.A.N.L.), Nuevo León, Mexico.

** Orthopedics and Traumatology Service, University Hospital “Dr. José Eleuterio González”, Universidad Autonóma de Nuevo León (U.A.N.L.), Nuevo León, Mexico. 
COMPEÁN-MARTÍNEZ, G. A.; MORALES-AVALOS, R.; VÍLCHEZ-CAVAZOS, F.; ACOSTA-OLIVO, C.; MENDOZA-LEMUS, O. F.; GARZA-CASTRO, O.; ELIZONDO-OMAÑA, R. E. \& GUZMÁN-LÓPEZ, S. Anthropometric landmarks for posterior cruciate ligament reconstruction in anatomical position. Int. J. Morphol., 33(2):678-684, 2015.

There is a lack of anatomical studies that clearly and precisely mention the anatomical insertion surface covered by each of the fascicles (AL and PM), as only the total insertion surface of the ligament is described (Triantafyllidi et al., 2013). This approach can result in inadequate graft placement, causing joint instability. The purpose of this study was to determine viable anatomical landmarks to facilitate the accurate locations of femoral and tibial tunnels in anatomical position during PCL reconstruction.

The hypothesis of this study was to demonstrate that the anatomical landmarks based on the center of the PCL provide precise anatomical points to locate femoral and tibial tunnels.

\section{MATERIAL AND METHOD}

This is an observational, cross-sectional and descriptive study. Ten knees (5 right and 5 left) belonging to the Macroscopic Anatomy Lab of the Human Anatomy Department of the Faculty of Medicine were dissected. Male cadavers were used, with an age range of 30-50 (mean
43) years old, a weight range of $68-88 \mathrm{~kg}$ (mean 70.4), height range of 1.52-1.89 $\mathrm{m}$ (mean 1.67) and a body mass index range of $19.21-32.37 \mathrm{~kg} / \mathrm{m} 2$ (mean $24.88 \mathrm{~kg} / \mathrm{m} 2$ ) PCL femoral and tibial insertions were analyzed, as was the PCL itself, along with its AL and PM fascicles.

To access the knee joint interior and to analyze PCL bony insertions and fascicles, the knee was flexed to 90 degrees. It was then sectioned, reflecting the quadriceps tendon from above. The ACL was resected, and the collateral ligaments were sectioned, which allowed for a wide and direct view of the PCL. A digital Vernier calibrator (Mitutoyo Digimatic w/Absolute Encoders- Series 500, with a millimetric scale and a margin of error of $0.01 \mathrm{~mm}$ ) was used to obtain the PCL femoral insertions, tibial insertions and the fascicles. Finally, we first observe if there was an anterior or posterior meniscofemoral ligament to report, then the PCL was resected to make accurate PCL measurements, afterwards we marked the femoral and tibial footprints with ink to identify de margins.

Before making the measurements of the PCL fascicles, we separated them by looking for the anatomical change of direction of the fibers and start a longitudinal dissection.

Measurement parameters in the PCL and its fascicles were the transverse lengths of tibial and femoral insertions and its central portion (median). These transverse lengths were taken in two planes: anteroposterior (AP) and mediolateral (ML) (Fig. 1).

PCL femoral and tibial insertion measurements were taken, as were features specific to the PCL. The measurement parameter in the femur was the length between the center of the PCL insertion to the articular cartilage margin (Fig. 2). Tibial measurements corresponded to the lengths between the PCL and ACL footprint margins; lengths between the PCL margin and the medial and lateral meniscus margins were measured (Fig. 3).

To take measurements of the femoral insertion, the "clock" system was used, which utilizes arthroscopic approaches to delimit the natural PCL position. This method allows us to obtain reference values to perform the femoral tunnel during graft placement. The procedure consisted of marking a circle simulating a clock, considering the footprint left by the PCL insertion in the femur as a central landmark. Another landmark was added, (AP). The central portion only determined the transverse length (TL). 
COMPEÁN-MARTÍNEZ, G. A.; MORALES-AVALOS, R.; VÍLCHEZ-CAVAZOS, F.; ACOSTA-OLIVO, C.; MENDOZA-LEMUS, O. F.; GARZA-CASTRO, O.; ELIZONDO-OMAÑA, R. E. \& GUZMÁN-LÓPEZ, S. Anthropometric landmarks for posterior cruciate ligament reconstruction in anatomical position. Int. J. Morphol., 33(2):678-684, 2015.

consisting of the articular cartilage margin, and was utilized as a superior and anterior limit. The lengths between the central point of the footprint left by the PCL and the femoral cartilage margin were measured, taking into account the following clock hand positions: $12,1,2$, and 3 (in right knees) and 12, 11, 10, and 9 (in left knees) (Fig. 2).

Ethical Considerations. The protocol was approved by the Local Health Research Committee.

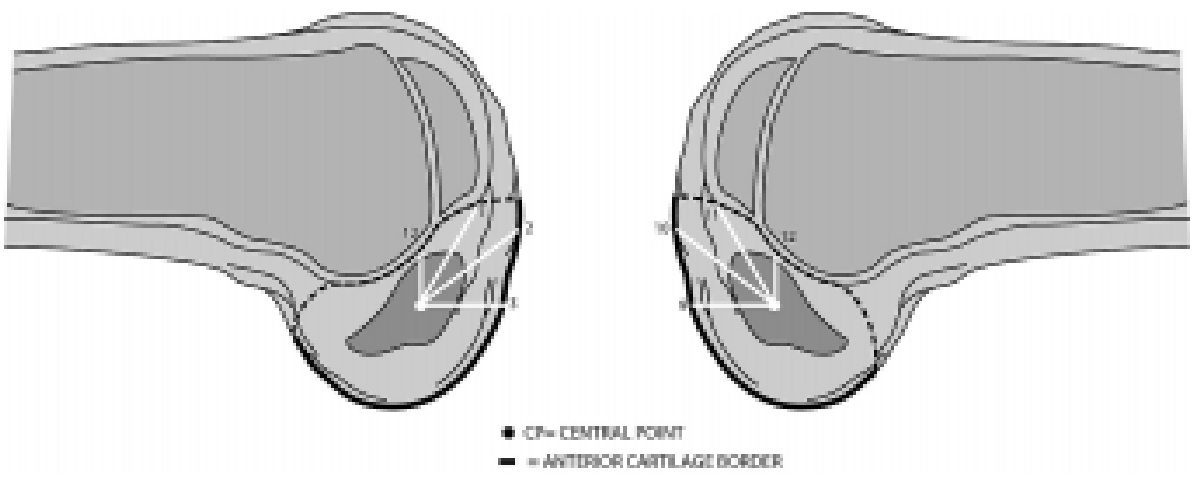

Fig. 2. Measurements of the femoral insertion of the PCL. Sagittal cut of the inferior epiphysis of the femur. The medial walls of the femoral intercondylar fossa in the right knee (1-a) and the left knee (1-b). The dotted line represents the extension of the intercondylar area. The thick line represents the articular cartilage of that area. The sketched lines between the central point of the footprint left by the PCL and the articular cartilage margin correspond to the lengths of the measurement parameters of the femoral insertion.
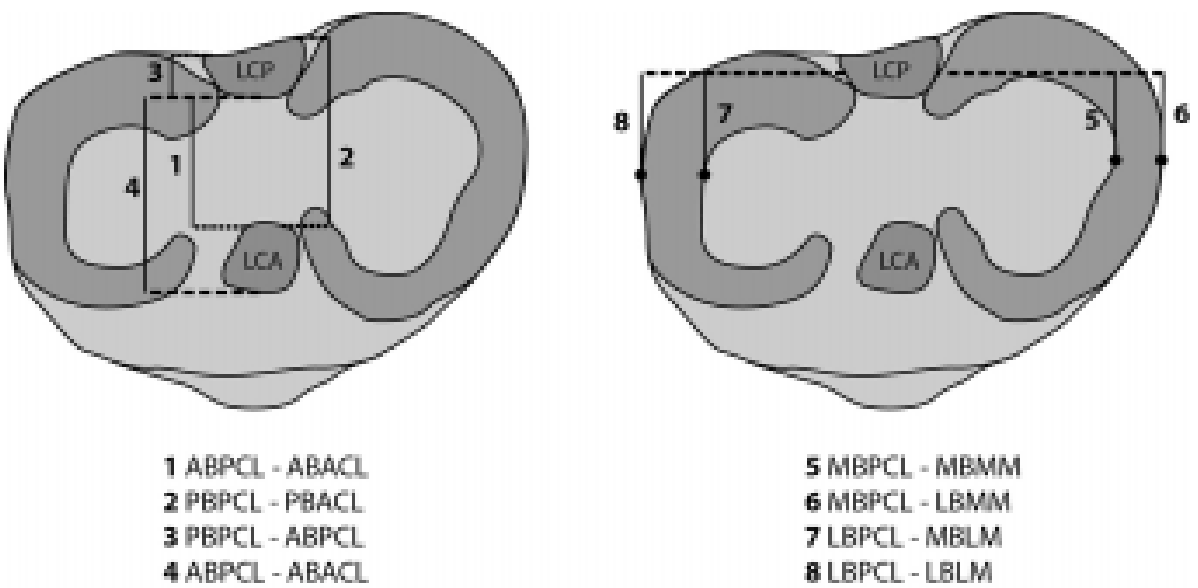

Fig. 3. Measurements of the tibial insertion of the PCL. Superior view of the superior epiphysis of the tibia. The tibial insertions of the PCL and ACL are observed, as are the medial and lateral menisci. The lengths that were measured between the PCL and ACL are represented, as are the distances between the PCL and the menisci margins. PBACL, posterior margin of the anterior cruciate ligament; ABPCL, anterior margin of the posterior cruciate ligament; PBPCL, posterior margin of the posterior cruciate ligament; ABACL, anterior margin of the anterior cruciate ligament; MBMM, medial margin of the medial meniscus; MBPCL, medial margin of the posterior cruciate ligament; LBMM, lateral margin of the medial meniscus; MBLM, medial margin of the lateral meniscus; LBPCL, lateral margin of the posterior cruciate ligament; LBLM, lateral margin of the lateral meniscus. 
COMPEÁN-MARTÍNEZ, G. A.; MORALES-AVALOS, R.; VÍLCHEZ-CAVAZOS, F.; ACOSTA-OLIVO, C.; MENDOZA-LEMUS, O. F.; GARZA-CASTRO, O.; ELIZONDO-OMAÑA, R. E. \& GUZMÁN-LÓPEZ, S. Anthropometric landmarks for posterior cruciate ligament reconstruction in anatomical position. Int. J. Morphol., 33(2):678-684, 2015.

\section{RESULTS}

Ten knees were included for which measurements of the PCL femoral and tibial insertions were taken, along with characteristics specific to the PCL and its fascicles.

Interobserver variability. No significant differences in the average results for each parameter measured between the two observers ( $p$ values ranging between 0.14 and 0.96 ) were found.

Measurements of PCL femoral insertions. Table I shows the measurements for the distance between the central point of the PCL footprint and the articular cartilage margin in each of the clock hand positions for left and right knees.

PCL tibial insertion measurements. Tibial measurements corresponded to the distance between the PCL and the ACL insertion margin. The mean of the distance of the anterior margin of the PCL to the posterior margin of the PCL was $21.88 \mathrm{~mm}( \pm 3.97)$; the means of the distance between the anterior margin of the PCL to the posterior margin of the ACL and the anterior margin of the PCL to the anterior margin of the ACL distance were $11.94 \mathrm{~mm}( \pm 5.08)$ and $26.62 \mathrm{~mm}( \pm 3.97)$, respectively; the mean of the distance between the posterior margin of the PCL to the posterior margin of the ACL distance was $33.47 \mathrm{~mm}( \pm 4.89)$.

The distance between the margin of the PCL insertion and the margins of the medial and lateral menisci were measured. The means of the lateral margin of the PCL to the lateral margin of the lateral meniscus and the lateral margin of the PCL to the medial margin of the lateral meniscus distance were $33.52 \mathrm{~mm}( \pm 3.49)$ and 21.09 $\mathrm{mm}( \pm 4.75)$, respectively. The means of the medial margin of the PCL to the lateral margin of the medial meniscus and the medial margin of the PCL to the medial margin of the medial meniscus were $32.24 \mathrm{~mm}( \pm 2.28)$ and 22.74 $\mathrm{mm}( \pm 5.46)$, respectively.

PCL measurements. PCL measurements were transverse femoral and tibial insertion lengths and the central portion length (mean). Additionally, the measurements of the anterolateral and posteromedial fascicles of the PCL were separately determined. From the AP viewpoint, the anterolateral fascicle occupied a greater surface than the posteromedial fascicle in its femoral insertion, central portion and tibial insertion (Table II). From the ML viewpoint, the anterolateral fascicle was greater in its femoral insertion and central portion than the posteromedial fascicle, but not in its tibial insertion (Table II).

Meniscofemoral ligaments. As for the anterior and posterior meniscofemoral ligaments, a prevalence of $60 \%$ was obtained for the posterior meniscofemoral ligament (Wrisberg), and a prevalence of $30 \%$ was obtained for the anterior meniscofemoral ligament (Humphrey).

Table I. Length from the central point of the PCL footprint to the articular cartilage margin.

\begin{tabular}{lcccccccc}
\hline \multirow{2}{*}{ Clock hands } & \multicolumn{2}{c}{$\mathbf{1 2}$} & \multicolumn{2}{c}{$\mathbf{1 / 1 1}$} & \multicolumn{2}{c}{$\mathbf{1 1 0}$} & \multicolumn{3}{c}{$\mathbf{3 / 9}$} \\
\cline { 2 - 10 } & Mean & SD & Mean & SD & Mean & SD & Mean & SD \\
\hline Rigth Knee & 17.23 & \pm 3.94 & 16.01 & \pm 4.51 & 14.52 & \pm 4.35 & 11.02 & \pm 3.82 \\
Left Knee & 17.73 & \pm 4.11 & 16.76 & \pm 3.62 & 14.19 & \pm 3.62 & 11.29 & \pm 3.35
\end{tabular}

The mean (mm) and standard deviations (SD) are shown. The clock hand positions are represented as 12, 1/11, 2/10, and 3/9 depending on the side of the knee (right/left, respectively).

Table II. Measurements taken for the PCL and its corresponding anterolateral and posterolateral fascicles.

\begin{tabular}{lcccccc}
\hline \multicolumn{7}{c}{ PCL } \\
Viewpoints & \multicolumn{7}{c}{ AP } & \multicolumn{4}{c}{ ML } \\
Portion & FI & CP & TI & FI & CP & TI \\
PCL (total) & $8.42 \pm 1.06$ & $6.10 \pm 0.98$ & $4.03 \pm 0.42$ & $17.33 \pm 1.17$ & $13.41 \pm 1.04$ & $17.54 \pm 3.07$ \\
Anterolateral & $6.65 \pm 1.28$ & $4.15 \pm 0.97$ & $2.79 \pm 0.80$ & $9.95 \pm 1.94$ & $9.89 \pm 0.76$ & $10.77 \pm 3.57$ \\
Posteromedial & $5.76 \pm 1.23$ & $3.78 \pm 1.08$ & $2.68 \pm 1.19$ & $8.59 \pm 1.52$ & $9.55 \pm 1.63$ & $12.39 \pm 1.04$ \\
\hline
\end{tabular}

Transverse femoral and tibial insertion lengths were included, along with the central portion length. These measurements were made from two viewpoints: anteroposterior (AP) and mediolateral (ML). TI, Tibial insertion; FI, Femoral insertion; CP, Central portion; AP, Anteroposterior; ML, Mediolateral; SD, Standard deviation. 
COMPEÁN-MARTÍNEZ, G. A.; MORALES-AVALOS, R.; VÍlCHEZ-CAVAZOS, F.; ACOSTA-OLIVO, C.; MENDOZA-LEMUS, O. F.; GARZA-CASTRO, O.; ELIZONDO-OMAÑA, R. E. \& GUZMÁN-LÓPEZ, S. Anthropometric landmarks for posterior cruciate ligament reconstruction in anatomical position. Int. J. Morphol., 33(2):678-684, 2015.

\section{DISCUSSION}

This study morphometrically describes PCL femoral and tibial insertions, their specific characteristics and those of their anterolateral and posteromedial fascicles. These results contribute relevant information that may be useful in the PCL reconstruction process. In this study, practical, simple and viable landmarks are proposed for the placement of femoral and tibial tunnels in anatomical position from an arthroscopic viewpoint.

Initial efforts in PCL reconstruction were based on knowledge of the strength and elasticity attributed to the AL fascicle, for which the single-bundle technique was developed (Fanelli et al., 2010). It is currently accepted that the AL and PM PCL fascicles contribute in a significant and balanced way to joint stability, even in different moments of flexion and extension (Giffin et al., 2002), which has generated controversy as to whether it is better to use the one- or two-bundle reconstruction technique. This study contributes information relevant for femoral and tibial tunnel placement in anatomical position.

Other studies have described PCL femoral and tibial insertions, their characteristics and those of their fascicles (Amis et al., 2006; Edwards et al.; Takahashi et al., 2006; Mejía et al., 2002; Girgis et al., 1975; Morgan et al., 1995; Morgan et al., 1997). The published studies on PCL femoral insertion have focused on determining the center of the print left by the ligament. Despite this knowledge, femoral tunnel placement is complex and is therefore a cause of posterior functional sequelae in reconstruction surgery (Mejia et al.). Efforts have been made to determine coordinates to locate the central point. Some authors utilize the clock hands system as a method to accomplish this goal (Apsingi et al.; Mejía et $a l$.). In this study, the same system was used, and the results confirm Mejia's et al. findings (2002) in the North American population. This study is the first performed in the Mexican population, which allows us to contribute our information to reports from other populations.

Due to the low percentage of associated complications, the PCL tibial insertion is a little-studied area. However, consideration of the intercondylar space anatomy of the tibia is important for accurate tunnel location. The study conducted by Takahashi et al., located the central points of the PCL and ACL, taking into account the distance between the meniscus margins. In our study, consideration was given to the lengths between the medial and lateral meniscus margins and the medial and lateral PCL and ACL margins. In addition, measurements between anterior and posterior PCL and ACL margins were studied. The lengths reported in this study are shorter compared to those in the Takahashi et al., study. This difference is because, in our study, we considered PCL margins rather than the center, as did the latter. We believe that in the case of PCL tibial insertions, it is advantageous to use the insertion margins because they offer greater precision. Additionally, other landmarks are added that can be useful to the surgeon while performing an arthroscopic PCL reconstruction.

Other studies have reported the transverse lengths at the femoral insertion, central portion and tibial insertion levels (Triantafyllidi et al.; Fanelli et al.; Sheps et al., 2005; Margheritini et al., 2004; Cosgarea \& Jay, 2001; Stähelin et al., 2001). Harner et al. (1999) discovered that the AL fascicle is greater than the PM, which differs from data reported by Takahashi et al. The results of this study are similar to those reported by Harner et al. After comparing our results with those of Triantafyllidi et al., we confirmed their results, particularly that the tibial insertion was opened in a fan shape along the greatest length (20.69 mm vs. $17.34 \mathrm{~mm})$.

The most relevant finding of this study was that the PCL did not have the same dimension for the entirety of its length, replicating the "sand clock" form with wide bases and a thin center, particularly in its anteroposterior length. This finding is important, as the grafts currently used in reconstruction (bone - tendon - bone, ischiotibial) do not have the characteristics of the native ligament. Therefore, those grafts that have greater diameters compared to the footprint left by the PCL in the medial femoral condyle will have a greater chance of causing an impingment of the osseous structures of the intercondylar region with the ACL.

PCL reconstruction is performed using grafts whose dimensions are measured before reconstruction. The carrying out of studies to evaluate the use of the most common grafts used for PCL reconstruction using the methods of the present study to determinate whether there are significant variations respect to the results obtained in this study. It is necessary to continue these research efforts to obtain an ideally formed graft that replicates the form of the native ligaments and that can improve the results obtained in PCL reconstructions.

This study has certain limitations. The accomplishment of similar studies with higher samples is necessary to establish precisely the morphometric parameters evaluated. The use of male cadavers during this study represents another limitation.

Reported femoral and tibial insertion lengths from the center of each of these structures are practical landmarks for femoral and tibial tunnel placements in anatomical position during PCL plasty. 
COMPEÁN-MARTÍNEZ, G. A.; MORALES-AVALOS, R.; VÍLCHEZ-CAVAZOS, F.; ACOSTA-OLIVO, C.; MENDOZA-LEMUS, O. F.; GARZA-CASTRO, O.; ELIZONDO-OMAÑA, R. E. \& GUZMÁN-LÓPEZ, S. Anthropometric landmarks for posterior cruciate ligament reconstruction in anatomical position. Int. J. Morphol., 33(2):678-684, 2015.

COMPEÁN-MARTÍNEZ, G. A.; MORALES-AVALOS, R.; VÍlCHEZ-CAVAZOS, F.; ACOSTA-OLIVO, C.; MENDOZALEMUS, O. F.; GARZA-CASTRO, O.; ELIZONDO-OMAÑA, R. E. \& GUZMÁN-LÓPEZ, S. Referencias antropométricas para la reconstrucción del ligamento cruzado posterior en posición anatómica. Int. J. Morphol., 33(2):678-684, 2015.

RESUMEN: El propósito del estudio fue determinar referencias anatómicas viables para la correcta colocación de los túneles femorales y tibiales en posición anatómica durante la reconstrucción del ligamento cruzado posterior (LCP). Se utilizaron 10 rodillas, las cuales fueron disecadas para analizar las mediciones de la inserción femoral y tibial del LCP, sus fascículos y estructuras adyacentes. Se utilizó el sistema de las manecillas del reloj para la medición de las inserciones femorales. Los meniscos y el ligamento cruzado anterior (LCA) fueron utilizados como referencias para la medición de las inserciones tibiales. El LCP y las características de sus fascículos correspondientes fueron determinados por su inserción femoral, porción central e inserción tibial. La media de la longitud entre la porción central de la huella dejada por el LCP y el margen anterior del cartílago femoral a las 12:00 h fue de $( \pm 3.94)$ y $17,73 \mathrm{~mm}( \pm 4,11)$ para la rodilla derecha e izquierda, respectivamente. La longitudes del LCP fueron de $11,94 \mathrm{~mm}( \pm 5,08)$ entre el margen posterior del LCP y el margen anterior del LCP. La media fue de $33,52 \mathrm{~mm}( \pm 3,49)$ desde el margen medial del menisco lateral al margen lateral del LCP y de 32,24 mm $( \pm 2,28)$ del margen medial del menisco medial al margen medial del LCP. Desde el punto de visión anteroposterior, el fascículo anterolateral es mayor que el posteromedial tanto en su inserción femoral como en el punto central e inserción tibial. Se analizó una colección cuantitativa de bases de datos con distintas variables del LCP, así como de sus fascículos y sus inserciones femorales y tibiales. Se obtuvieron varias medidas, indicando la alta funcionalidad compartida por los fascículos del LCP. Las inserciones reportadas son referencias prácticas para la localización de los túneles tibiales y femorales durante la plastía del ligamento cruzado posterior.

PALABRAS CLAVE: Ligamento cruzado posterior; Tuneles femorales; Reconstrucción; Anatomía; Puntos de referencia.

\section{REFERENCES}

Amis, A. A.; Bull, A. M.; Gupte, C. M.; Hijazi, I.; Race, A. \& Robinson J. R. Biomechanics of the PCL and related structures: posterolateral, posteromedial and meniscofemoral ligaments. Knee Surg. Sports Traumatol. Arthrosc., 11(5):271-81, 2003.

Amis, A. A.; Gupte, C. M.; Bull, A. M. \& Edwards, A. Anatomy of the posterior cruciate ligament and the meniscofemoral ligaments. Knee Surg. Sports Traumatol. Arthrosc., 14(3):257-63, 2006.

Apsingi, S.; Bull, A. M.; Deehan, D. J. \& Amis, A. A. Review: femoral tunnel placement for PCL reconstruction in relation to the PCL fibre bundle attachments. Knee Surg. Sports Traumatol. Arthrosc., 17(6):652-9, 2009.

Cosgarea, A. J. \& Jay, P. R. Posterior cruciate ligament injuries: evaluation and management. J. Am. Acad. Orthop. Surg., 9(5):297-307, 2001.

Edwards, A.; Bull A. M. \& Amis, A. A. The attachments of the fiber bundles of the posterior cruciate ligament: an anatomic study. Arthroscopy, 23(3):284-90, 2007.

Fanelli, G. C.; Beck, J. D. \& Edson, C. J. Current concepts review: the posterior cruciate ligament. J. Knee Surg., 23(2):61-72, 2010.

Giffin, J. R.; Haemmerle, M. J.; Vogrin, T. M. \& Harner, C. D. Single- versus double-bundle PCL reconstruction: a biomechanical analysis. J. Knee Surg., 15(2):114-20, 2002.

Girgis, F. G.; Marshall, J. L. \& Monajem, A. The cruciate ligaments of the knee joint. Anatomical, functional and ex- perimental analysis. Clin. Orthop. Relat. Res., (106):216$31,1975$.

Harner, C. D.; Baek, G. H.; Vogrin, T. M.; Carlin, G. J.; Kashiwaguchi, S. \& Woo, S. L. Quantitative analysis of human cruciate ligament insertions. Arthroscopy, 15(7):741-9, 1999.

Kennedy, J. C.; Hawkins, R. J.; Willis, R. B. \& Danylchuck, K. D. Tension studies of human knee ligaments. Yield point, ultimate failure, and disruption of the cruciate and tibial collateral ligaments. J. Bone Joint Surg. Am., 58(3):350-5, 1976.

Margheritini, F.; Mauro, C. S; Rihn, J. A.; Stabile, K. J.; Woo, S. L. $\&$ Harner C. D. Biomechanical comparison of tibial inlay versus transtibial techniques for posterior cruciate ligament reconstruction: analysis of knee kinematics and graft in situ forces. Am. J. Sports Med., 32(3):587-93, 2004.

Marinozzi, G.; Pappalardo, S. \& Steindler, R. Human knee ligaments: mechanical tests and ultrastructural observations. Ital. J. Orthop. Traumatol., 9(2):231-40, 1983.

Markolf, K. L.; Feeley, B. T.; Jackson, S. R. \& McAllister, D. R. Biomechanical studies of double-bundle posterior cruciate ligament reconstructions. J. Bone Joint Surg. Am., 88(8):178894, 2006.

Mejia, E. A. Noyes, F. R. \& Grood, E. S. Posterior cruciate ligament femoral insertion site characteristics. Importance for reconstructive procedures. Am. J. Sports Med., 30(5):643-51, 2002.

Morgan, C. D.; Kalman, V. R. \& Grawl, D. M. Definitive landmarks for reproducible tibial tunnel placement in ante- 
COMPEÁN-MARTÍNEZ, G. A.; MORALES-AVALOS, R.; VÍLCHEZ-CAVAZOS, F.; ACOSTA-OLIVO, C.; MENDOZA-LEMUS, O. F.; GARZA-CASTRO, O.; ELIZONDO-OMAÑA, R. E. \& GUZMÁN-LÓPEZ, S. Anthropometric landmarks for posterior cruciate ligament reconstruction in anatomical position. Int. J. Morphol., 33(2):678-684, 2015.

rior cruciate ligament reconstruction. Arthroscopy, 11(3):275$88,1995$.

Morgan, C. D.; Kalman, V. R. \& Grawl, D. M. The anatomic origin of the posterior cruciate ligament: where is it? Reference landmarks for PCL reconstruction. Arthroscopy, 13(3):325-31, 1997.

Race, A. \& Amis, A. A. The mechanical properties of the two bundles of the human posterior cruciate ligament. J. Biomech., 27(1):13-24, 1994.

Sheps, D. M.; Otto, D. \& Fernhout, M. The anatomic characteristics of the tibial insertion of the posterior cruciate ligament. Arthroscopy, 21(7):820-5, 2005.

Stähelin, A. C.; Südkamp, N. P. \& Weiler, A. Anatomic doublebundle posterior cruciate ligament reconstruction using hamstring tendons. Arthroscopy, 17(1):88-97, 2001.

Takahashi, M.; Matsubara, T.; Doi. M.; Suzuki, D. \& Nagano, A. Anatomical study of the femoral and tibial insertions of the anterolateral and posteromedial bundles of human posterior cruciate ligament. Knee Surg. Sports Traumatol. Arthrosc., 14(11):1055-9, 2006.

Triantafyllidi, E.; Paschos, N. K.; Goussia, A.; Barkoula, N. M.; Exarchos, D. A.; Matikas, T. E.; Malamou-Mitsi, V. \& Georgoulis, A. D. The shape and the thickness of the anterior cruciate ligament along its length in relation to the posterior cruciate ligament: a cadaveric study. Arthroscopy, 29(12):196373, 2013.

\author{
Correspondence to: \\ Rodrigo E. Elizondo-Omaña, M.D. PhD. \\ Department of Human Anatomy \\ Faculty of Medicine \\ Universidad Autónoma de Nuevo León (U.A.N.L.) \\ Ave. Madero s/n Col. \\ Mitras Centro \\ Monterrey \\ Nuevo León, C.P. 64460 \\ MÉXICO
}

Email: rod_omana@yahoo.com

Received: 25-11-2014

Accepted: 10-03-2015 